\title{
Antioxidant activities, proteolytic activity and growth behavior of Lactobacillus cultures during fermentation of goat milk
}

\author{
Gauravkumar Panchal $^{1}$, Subrota Hati ${ }^{1}$, VB Darji ${ }^{2}$ and JB Prajapati ${ }^{1}$
}

Received: 05 July 2019 / Accepted: 20 October 2019 / Published online: 27 February 2020

(C) Indian Dairy Association (India) 2020

\begin{abstract}
In the study, five Lactobacillus cultures i.e. Lb. fermentum (M3), Lb. casei (NK9), Lb. rhamnosus (M8), Lb. rhamnosus (M9) and Lb. paracasei (M11) were used for the fermentation of goat milk. Lactobacillus cultures were evaluated for their growth behavior on $\mathrm{pH}$, acidity and Lactobacillus counts for different time periods. We found that $\mathrm{pH}$ reduction by Lactobacillus cultures in goat milk medium was ranged from $\mathrm{pH}$ 6.25 at $0 \mathrm{~h}$ to $\mathrm{pH} 3.06$ after $48 \mathrm{~h}$ at $37^{\circ} \mathrm{C}$, for acidity produced by Lactobacillus cultures was ranged from 0.28 in $0 \mathrm{~h}$ to $3.21 \% \mathrm{LA}$ after $48 \mathrm{~h}$ at $37^{\circ} \mathrm{C}$ and for lactic counts (log CFU/ml) were ranged from $3.87 \log \mathrm{CFU} / \mathrm{ml}$ at $0 \mathrm{~h}$ to $9.03 \log \mathrm{CFU} / \mathrm{ml}$ after $36 \mathrm{~h}$ incubation at $37^{\circ} \mathrm{C}$. Then, antioxidant activities (ABTS assay, Hydroxyl free radical scavenging assay and Superoxide free radical scavenging assay) as well as proteolytic activity (OPA method) were analyzed for different time periods and found that antioxidant activity (ABTS assay) of Lactobacillus cultures was in the range of 42.14 to $53.27 \%$, hydroxyl free radical scavenging activity of Lactobacillus cultures was found in the range of 35.32 to $53.43 \%$, superoxide free radical scavenging activity of Lactobacillus cultures was in the range of $24.34 \%$ to $50.99 \%$ and proteolytic (OPA) activity of Lactobacillus cultures was found in the range of 7.30 to $9.96 \mathrm{mg} / \mathrm{ml}$.
\end{abstract}

Keywords: Antioxidant activity, Capra aegagrus hircus, Fermented Goat milk, Proteolytic

${ }^{1}$ Dept. of Dairy Microbiology, Anand Agricultural University, Anand388 110, Gujarat, India

${ }^{2}$ CAIT, Anand Agricultural University, Anand-388 110, Gujarat, India, Email: vbdarji@aau.in

Subrota Hati $(\bowtie)$

Dept. of Dairy Microbiology, Anand Agricultural University, Anand-388 110, Gujarat, India Email: subrota_dt@yahoo.com, Mobile No. +91-9409669561

\section{Introduction}

In Mesopotamia, part of today's the Middle East, Goats (Capra aegagrus hircus) were the first species to be domesticated as livestock about 8000 BC. For centuries, humans have been used goats for many purposes (milk and meat) in all continents (Zervas and Tsiplakou, 2011). Goat milk production is an important part of the economy in many countries such as Spain, Switzerland, Italy, France, Turkey and New Zealand. On a global basis, different varieties of cheese, yoghurt, ice cream, fluid milk and milk powder are produced from goat milk. Goat milk production in the country has also increased from 3.6 to 4.7 million tons during the same period with an annual growth rate of 2.6 Per cent. The country stands first in goat milk production and is the second largest in goat meat production in the world by sharing 29 Per cent and 12 Per cent production, respectively (CIRG, 2015-2016).

Goat milk is nutritional and therapeutic food. Goat milk differs from cow or human milk in the context of higher digestibility, distinct alkalinity, higher buffering capacity and certain therapeutic in medicine and human nutrition (Park, 2009). Goat milk proteins may be digested more freely and their amino acids absorbed more efficiently than those of cow milk. Goat milk is considered to form a softer, more friable curd when acidified, which may be related to lower contents of $\alpha$ s1-casein and in the milk (Zenebe et al. 2014). Goat milk is good for ulcer treatment because it has better buffering capacity due to higher non-protein nitrogen (NPN) than cow milk (Park, 2009). The protein content of goat milk is quite similar to that of cow milk, although the caseins content in goat milk is slightly higher, and there is great homology between major proteins. However, $\beta$-casein is the major protein in goat milk (50 Per cent of total caseins), which is in contrast to cow milk where $\beta$-casein and $\alpha$ s1-casein are almost equally abundant, 37 Per cent and 30 Per cent, respectively (da Costa et al. 2014).

Many of the Lactic Acid Bacteria (LAB) were isolated from goat milk. Badis et al. (2004) isolated 725 lactic acid bacteria from raw goat milk of four Algerian races. They were phenotypically classified as Lactobacillus, Lactococcus, Leuconostoc, Streptococcus and Pediococcus. Da Silva et al. (2016) too isolated riboflavin and folate producing 179 lactic acid bacteria from goat milk and cheeses from these predominance species are 
Streptococcus thermophilus, Weissella paramensenteroides, and Lactococcus lactis. $84 \%$ of isolates were able to produce folate, $8 \%$ riboflavin and $8 \%$ both vitamins. Goat milk fermented with different $\mathrm{LAB}$ increase the biologically active peptides from corresponding sequences of the precursor protein. The health benefits of the bioactive peptides may be attributed to their demonstrated antimicrobial, antioxidant, antihypertensive, antithrombotic, immune-modulatory and opioid activities (Sharma et al. 2017: Parmar et al. 2018).

Generally, chronic diseases and ageing phenomena are relevant to the imbalance in free radical levels in the body. An excess of free radicals can cause lethal cellular effects by oxidizing membrane lipids, cellular proteins, DNA, and enzymes, thus shutting down cellular respiration (Rahal et al. 2014; Urso and Clarkson, 2003). To prevent foods from undergoing deterioration and to provide protection against serious oxidative related diseases, it is important to prevent the peroxidation of lipids and the formation of free radicals generating in the living body and foodstuffs. Lipid oxidation is inhibited by antioxidant agents (Chen et al., 2018; Kondyli et al. 2007). Artificial antioxidants, such as butylated hydroxyanisole, butylated hydroxytoluene, and n-propyl gallate, exhibit strong antioxidant activity against several oxidation systems. However, the use of artificial antioxidants in foodstuffs is restricted or prohibited in some countries because of the potential risks for the living body. Antioxidants from natural sources are receiving increased attention. Food-derived peptides have been demonstrated to be the natural antioxidants without marked adverse effects. An increasing number of food protein hydrolysates and antioxidant peptides have been found to exhibit antioxidant activity (Samaranayaka and Li-Chan, 2011). Goat milk casein (GMC) differs greatly from bovine casein in content, peptide chain length, and Amino acid sequences (Kondyli et al. 2007; Ceballos et al. 2009). The study aims to evaluate the antioxidant activities, proteolytic activity and growth behaviour of Lactobacillus cultures during fermentation of goat milk.

\section{Materials and Methods}

\section{Materials and culture collection}

In this study, Most of the bacteriological grade media, molecular biology grade chemicals and reagents were purchased either from Hi-media (Mumbai), Merck (Germany), Sigma (USA), Bio-Rad, Promega, Ameresco, MP Biomedicals. Lb. fermentum (M3), Lb. casei (NK9), Lb. rhamnosus (M8), Lb. rhamnosus (M9) and Lb. paracasei (M11) were procured from the Culture Collection of Dairy Microbiology Department, Sheth M. C. College of Dairy Science, Anand Agricultural University, Anand, Gujarat, India. Sterilized reconstituted skim milk with $12 \%$ Total solids was used for the propagation of lactic culture and further stored at $5 \pm 2{ }^{\circ} \mathrm{C}$.

\section{Procurement of Goat milk (Capra aegagrus hircus)}

Goat milk of Surti breed (Capra aegagrus hircus) was procured from Instructional Livestock Farm Complex (ILFC), Veterinary College, AAU, Anand during the study.

\section{Determination of pH, acidity and lactic counts of fermented goat milk}

All the cultures were activated by growing in sterilized goat milk. The activated cultures were added to $100 \mathrm{ml}$ of sterilized goat milk flasks at a rate of $2 \%$. After mixing them thoroughly, culture flasks were incubated at $37^{\circ} \mathrm{C}$ for different time intervals i.e. 0,6 , $12,24,36$ and $48 \mathrm{~h}$. Then flasks were taken out for the determination of $\mathrm{pH}$, titratable acidity and lactic counts.

\section{Determination of $\mathrm{pH}$}

$\mathrm{pH}$ of fermented goat milk was determined as per the procedure described in Indian Standard (1961) with a calibrated $\mathrm{pH}$ meter (OAKTON pH700, India). Well mixed $10 \mathrm{ml}$ fermented goat milk sample was put into a beaker and then $\mathrm{pH}$ was measured by immersing the $\mathrm{pH}$ meter probe into the fermented milk sample. Standard buffer solution of $\mathrm{pH} \mathrm{4,7}$ and 9 was used to calibrate the $\mathrm{pH}$ meter before measuring the sample.

\section{Determination of titratable acidity}

The titratable acidity was estimated by the procedure described in Indian Standard (1960). $10 \mathrm{ml}$ sample was taken after each interval of $0,6,12,24,36$ and $48 \mathrm{~h}$ into porcelain dish and an equal volume of lukewarm distilled water was added to it, then $1.0 \mathrm{ml}$ phenolphthalein indicator was added and the contents of dish were titrated against $0.1[\mathrm{~N}] \mathrm{NaOH}$ till the appearance of light pink colour, which persisted for 30 seconds in the solution. Titratable acidity was calculated by the following formula:

Acidity $(\%$ Lactic acid $)=9 \times \mathrm{V} \times \mathrm{NX}$

Where,

$\mathrm{V}=$ Volume $(\mathrm{ml})$ of $0.1[\mathrm{~N}] \mathrm{NaOH}$ required for the titration,

$\mathrm{N}=$ Normality of $\mathrm{NaOH}$ solution and

$\mathrm{X}=$ Volume of milk $(\mathrm{ml})$ taken for the titration

\section{Determination of lactic counts}

Lactobacillus counts of fermented goat milk samples were determined as per the method described by IDF standards (146:2003). $1.0 \mathrm{ml}$ sample was taken out from the tubes and added to $9 \mathrm{ml}$ phosphate buffer tubes. Similarly, as per the required number of serial dilutions were prepared. $1.0 \mathrm{ml}$ diluted sample from appropriate tubes was transferred to labelled sterile Petri plates (performed in duplicates), then $15-20 \mathrm{ml}$ of melted and 
cooled $\left(45^{\circ} \mathrm{C}\right)$ MRS agar was poured to each Petri plates. The content was mixed thoroughly by tilting and rotating the plates and allowed it to solidify and then add second layer $(5-7 \mathrm{ml})$ of the same agar was poured completely over the solidified medium. Again allowed it to solidify, then incubated at $37^{\circ} \mathrm{C}$ for $24 \mathrm{~h}$ in the inverted position. Typical colonies were calculated and the counts were expressed as $\log \mathrm{CFU} / \mathrm{ml}$.

\section{Assessment of antioxidant activities (ABTS assay, Hydroxyl free radical scavenging assay and Superoxide free radical scavenging assay) of Lactobacillus cultures}

\section{Sample preparation}

Fresh goat milk was collected. Then filtered through a muslin cloth and sterilized at $121^{\circ} \mathrm{C}\left(250^{\circ} \mathrm{F}\right)$ at $15 \mathrm{psi}$ (pounds per square inch) for 15 minutes and stored at $5 \pm 1^{\circ} \mathrm{C}$. The pure culture was activated by inoculating in sterilized goat milk at the rate of $2 \%$ and incubated at $37^{\circ} \mathrm{C}$ for $24 \mathrm{~h}$. Further, sampling was carried out by inoculating each culture in $10 \mathrm{ml}$ sterilized goat milk at the rate of $2 \%$ and incubated for 0 and $48 \mathrm{~h}$ at $37^{\circ} \mathrm{C}$. After incubation of 0 , $12,24,36$ and $48 \mathrm{~h}$, the fermented goat milk samples were centrifuged at $14,000 \mathrm{rpm}$ for $30 \mathrm{~min}$ at $4^{\circ} \mathrm{C}$ (Eppendorf centrifuge, US). The supernatants were collected and filtered using $0.22 \mu \mathrm{m}$ syringe filter (Millex ${ }^{\circledR}-\mathrm{HV}, \mathrm{MERK}$, Ireland) and stored further for evaluating the antioxidant activities.

\section{ABTS assay (2, 2-Azino-bis (3-ethylbenzothaizoline 6-sulfonic acid) assay) of fermented goat milk}

The radical scavenging capacity of Lactobacillus cultures was based on the capability of a compound to scavenge the stable ABTS radical. This assay was evaluated as per the method described by Hati et al. (2013) with some modification. The ABTS working solution was prepared in dark bottle by mixing $88 \mu \mathrm{L}$ of $140 \mathrm{mM}$ potassium persulphate with $5 \mathrm{~mL}$ of $7 \mathrm{mM}$ ABTS stock solution and incubating overnight for the generation of radicals and was diluted with phosphate buffer saline (PBS) to adjust the absorbance at $734 \mathrm{~nm}$ to $0.7 \pm 0.02$. An aliquot of $200 \mu \mathrm{L}$ of product supernatant was mixed with $2.3 \mathrm{ml}$ ABTS in PBS solution and both were mixed for $10 \mathrm{sec}$. The decrease in absorbance at 734 $\mathrm{nm}$ was recorded over for $10 \mathrm{~min}$ at $10 \mathrm{sec}\left(\mathrm{A}_{\text {Sample }}\right)$ using Spectrophotometer (Systronics PC based double beam Spectrophotometer 2202, India). Unfermented goat milk supernatant was used as a control sample $\left(\mathrm{A}_{\text {Control }}\right)$. Free radical scavenging capacity of the peptides was measured using the following equation:

ABTS radical scavenging activity $(\%)=\left(\mathrm{A}_{\text {Control }}-\mathrm{A}_{\text {Sample }} / \mathrm{A}_{\text {Control }}\right)$ $\mathrm{x} 100$

\section{Hydroxyl free radical scavenging assay of fermented goat milk}

Antioxidant activity was carried out by using Hydroxyl free radical scavenging ability of the peptides following Li et al. (2008) with some modification. A mixture of $3 \mathrm{ml}$ phenanthroline $(0.75 \mathrm{mM})$ and $1.5 \mathrm{ml} \mathrm{FeSO}_{4}(0.75 \mathrm{mM})$ in phosphate buffer $(\mathrm{pH} 7.4)$ was prepared, and after adding $2 \mathrm{ml} \mathrm{H}_{2} \mathrm{O}_{2}(0.01 \%)$ and $1 \mathrm{ml}$ supernatant, then the mixture was incubated at $37^{\circ} \mathrm{C}$ for 1 hour. Ultimately, the absorbance was evaluated at $536 \mathrm{~nm}$. Hydroxyl free radical scavenging capacity of the peptides was evaluated by the following equation:

Hydroxyl radical scavenging activity $(\%)=\left[\left(\mathrm{A}_{\mathrm{S}}-\mathrm{A}_{1}\right) /\left(\mathrm{A}_{0}-\right.\right.$ $\left.\left.A_{1}\right)\right] \times 100$

Where $\mathrm{A}_{\mathrm{s}}$ is the absorbance of the sample; $\mathrm{A}_{1}$ is the absorbance of the control containing 1, 10-phenanthroline, $\mathrm{FeSO}_{4}$ and $\mathrm{H}_{2} \mathrm{O}_{2}$; and $\mathrm{A}_{0}$ is the absorbance of the blank containing 1, 10phenanthroline and $\mathrm{FeSO}_{4}$.

\section{Superoxide free radical scavenging assay of fermented goat milk}

This method is based on the ability of peptides to scavenge $\mathrm{O}_{2}^{-}$ through the production of a chromophoric compound during the reaction. This assay was followed by Liu et al. (2010) with some modification. In this method, $800 \mu \mathrm{l}$ of supernatant along with $800 \mu \mathrm{l}$ of Tris-HCl buffer $(0.05 \mathrm{M}, \mathrm{pH} 8.3)$ was placed in a clean test tube; thereupon, $400 \mu \mathrm{l}$ of pyrogallol solution $(1.5 \mathrm{mM})$ was added. Finally, the absorption of the mixture was measured at 320 $\mathrm{nm}$ for 5 minutes at $25^{\circ} \mathrm{C}$. Butylated hydroxytoluene (at $0-1 \mathrm{mg} /$ $\mathrm{mL}$, final concentration) was used as a positive control (AC) to evaluate the superoxide free radical scavenging capacity of the sample (AS):

Superoxide radical scavenging $(\%)=$

$[(\Delta \mathrm{AC} / \mathrm{min})-(\Delta \mathrm{AS} /$ $\mathrm{min})] /(\Delta \mathrm{AC} / \mathrm{min}) \times 100$

\section{Assessment of proteolytic activity}

The proteolytic activity of Lactobacillus cultures was optimized by measuring the peptide content through O-phthalaldehyde (OPA) method (Hati et al., 2015; Solanki et al., 2017). Lactobacillus cultures were activated by growing in sterilized goat milk. The activated cultures were added to $10 \mathrm{ml}$ tubes of sterilized goat milk at the $2 \%$ rate of inoculation and incubated at different times intervals $(0,6,12,24,36$ and $48 \mathrm{~h})$. Then the samples were taken out for the evaluation of peptide content (Proteolytic activity) after each interval. The degree of proteolysis during fermentation of milk was determined by measuring the release of free $\mathrm{NH}_{3}$ groups following the O-phthalaldehyde (OPA) method. An aliquot of $3 \mathrm{ml}$ from each fermented goat milk sample was mixed with $5 \mathrm{ml}$ of $0.75 \%$ trichloroacetic acid (TCA) and vortexed for 1 min and then the mixture was filtered using Whatman no. 42 filter papers (UK). The filtrate $(200 \mu \mathrm{l})$ was added to $3 \mathrm{ml}$ of OPA reagent and after incubation at room temperature $\left(20^{\circ} \mathrm{C}\right)$ for $2 \mathrm{~min}$, the absorbance of the solution was measured by a Spectrophotometer (Systronics PC based double beam Spectrophotometer 2202, India) at $340 \mathrm{~nm}$. 


\section{Statistical analysis}

According to the statistical methods, all the study parameters were analyzed. Every experiment of the study was performed at least in triplicates with the results expressed as means (Average) \pm standard deviations (SD). Statistical designs and software were used to analyze the experimental data. Using $5.0 \%$ level of significance and analysis of variance (ANOVA), the significant difference between the treatments was evaluated (Steel and Torrie, 1980).

\section{Result and Discussion}

\section{Growth behaviour of Lactobacillus cultures in goat milk medium}

The each Lactobacillus culture was inoculated at the rate of $2 \%$ in sterilized goat milk and then $\mathrm{pH}$, titratable acidity (\% Lactic acid) and Lactobacillus counts were evaluated at different time intervals $(0,6,12,24,36$ and $48 \mathrm{~h})$ at $37^{\circ} \mathrm{C}$. The $\mathrm{pH}$ reduction, titratable acidity (\%LA) and Lactobacillus counts of individual Lactobacillus culture were determined.

\section{pH}

$\mathrm{pH}$ reduction by Lactobacillus cultures in goat milk was ranged from $\mathrm{pH} 6.25$ at $0 \mathrm{~h}$ to $\mathrm{pH} 3.06$ after $48 \mathrm{~h}$ at $37^{\circ} \mathrm{C}$. M8 showed maximum $\mathrm{pH}$ reduction ( $\mathrm{pH} 3.06$ ) followed by $\mathrm{M} 3$ ( $\mathrm{pH} 3.11$ ), NK9 $(\mathrm{pH} 3.18), \mathrm{M} 9(\mathrm{pH} 3.32)$ and $\mathrm{M} 11(\mathrm{pH} 3.42)$ after $48 \mathrm{~h}$ at $37^{\circ} \mathrm{C}$ (Fig. 1).

\section{Titratable acidity}

Titratable acidity was determined by calculating the amount of acidity developed up to $48 \mathrm{~h}$ of incubation by the formula given in (2.3.2). The acidity produced by Lactobacillus cultures was ranged from 0.28 in $0 \mathrm{~h}$ to $3.21 \% \mathrm{LA}$ after $48 \mathrm{~h}$ at $37^{\circ} \mathrm{C}$. During the growth in sterilized goat milk, M8 showed highest titratable acidity (3.18\%LA), followed by M3 (3.17\%LA), NK9 (3.05\%LA), M9 (2.73\%LA) and M1 (2.08\%LA) after 48 h at $37^{\circ} \mathrm{C}$ (Fig. 2).

\section{Lactobacillus counts}

Lactobacillus counts ( $\log \mathrm{CFU} / \mathrm{ml})$ of all the Lactobacillus cultures were evaluated for $0,6,12,24,36$ and $48 \mathrm{~h}$ at $37^{\circ} \mathrm{C}$. Overall lactic counts (log CFU/ml) were ranged from $3.87 \mathrm{log}$ $\mathrm{CFU} / \mathrm{ml}$ at $0 \mathrm{~h}$ to $9.03 \log \mathrm{CFU} / \mathrm{ml}$ after $36 \mathrm{~h}$ incubation at $37^{\circ} \mathrm{C}$ (Fig. 3). Different cultures treatment and time periods showed significant behaviour but the interaction of both varied nonsignificantly. Non-significant increases in viable counts were observed among the five Lactobacillus up to $24 \mathrm{~h}$ and growth was significantly $(\mathrm{P}<0.05)$ decrease after $48 \mathrm{~h}$ at $37^{\circ} \mathrm{C}$ in the study. M8 exhibited maximum growth (9.03 $\log \mathrm{CFU} / \mathrm{ml})$, followed by
M11 $(9.00 \log \mathrm{CFU} / \mathrm{ml})$ up to $36 \mathrm{~h}$ than decrease after $48 \mathrm{~h}$ at $37^{\circ} \mathrm{C}$. NK9 (8.98 $\log$ CFU/ml), M9 (8.62 log CFU/ml) and M3 (8.61 log $\mathrm{CFU} / \mathrm{ml}$ ) up to $24 \mathrm{~h}$ than decrease after $48 \mathrm{~h}$ at $37^{\circ} \mathrm{C}$. In one study, Parmar et al. (2018) studied the growth and acidification of five selected lactic acid bacteria in heat-treated goat milk. Among five Lactobacillus cultures (L. rhamnosus (NK2), L. casei (NK9), $L$. fermentum (M5), L. paracasei (M16) and L.fermentum TDS030603 (MTCC 25067) (LF)) studied, during the growth in heat-treated goat milk, M5 showed highest titratable acidity (3.25\%LA), followed by LF (3.17\%LA), NK2 (3.13\%LA), NK9 (2.88\%LA) and M16 $(1.72 \% \mathrm{LA})$ after $48 \mathrm{~h}$ at $37^{\circ} \mathrm{C}$. Maximum $\mathrm{pH}$ reduction showed M5 (pH 3.10) followed by NK9 (pH 3.14), NK2 (pH 3.25), LF (pH 3.28 ) and $\mathrm{M} 16$ exhibited lowest $\mathrm{pH}$ reduction $(\mathrm{pH} 4.20)$ after $48 \mathrm{~h}$ at $37^{\circ} \mathrm{C}$. Significant increases in viable counts were observed among the five lactic acid bacteria up to $12 \mathrm{~h}$ than growth was significantly $(\mathrm{P}<0.05)$ decrease after $48 \mathrm{~h}$ at $37^{\circ} \mathrm{C}$ in the study. M16 exhibited maximum growth $(9.35 \log \mathrm{CFU} / \mathrm{ml})$, followed by $\mathrm{LF}$ (8.82 $\log \mathrm{CFU} / \mathrm{ml}), \mathrm{NK} 9(8.80 \log \mathrm{CFU} / \mathrm{ml}), \mathrm{NK} 2$ (8.65 log CFU/ $\mathrm{ml})$ and M5 (8.18 $\log \mathrm{CFU} / \mathrm{ml})$ up to $12 \mathrm{~h}$ than decrease after $48 \mathrm{~h}$ at $37^{\circ} \mathrm{C}$ except M5 as we found.

Similar kind of result was also found by Solanki et al. (2017) that studied the growth and acidification of nine selected lactic acid bacteria in heat treated camel milk. Among nine lactic acid cultures (Lb. rhamnosus (NS4 and NS6), Lb. acidophilus (298), Lb. helveticus (V3), Lb. acidophilus (015), Str. thermophilus (MD2), Lb. bulgaricus (09), Lactococcus lactis ssp. lactis (NK6) and Lb. fermentum (LBF)) studied, during the growth in heat treated camel milk, V3 showed highest titratable acidity $(2.548 \% \mathrm{LA})$, followed by $09(2.487 \% \mathrm{LA}), \mathrm{LBF}(2.450 \% \mathrm{LA}), 015$ (2.422\%LA), NS6 (1.732\%LA), 298 (1.333\%LA), NS4 (1.221\%LA), MD2 (0.836\%LA) and NK6 $(0.785 \% \mathrm{LA})$ after $48 \mathrm{~h}$ at $37^{\circ} \mathrm{C}$. Maximum $\mathrm{pH}$ reduction showed V3 (pH 3.16) followed by 09 (pH 3.17), LBF (pH 3.27), 015 $(\mathrm{pH} 3.30), \mathrm{NS} 6$ ( $\mathrm{pH} 3.44), 298$ ( $\mathrm{pH} 3.55), \mathrm{NS} 4(\mathrm{pH} 4.00), \mathrm{MD} 2$ (pH 4.49) and NK6 exhibited lowest $\mathrm{pH}$ reduction ( $\mathrm{pH} 4.79$ ) after $48 \mathrm{~h}$ at $37^{\circ} \mathrm{C}$. Maximum lactic count $(\log \mathrm{CFU} / \mathrm{ml})$ exhibited by NS6 (11.62 $\log \mathrm{CFU} / \mathrm{ml})$ followed by 09 (11.33 $\log \mathrm{CFU} / \mathrm{ml}), \mathrm{NK} 6(10.51$ $\log \mathrm{CFU} / \mathrm{ml}), \mathrm{MD} 2(10.40 \log \mathrm{CFU} / \mathrm{ml}), \mathrm{V} 3(10.20 \log \mathrm{CFU} / \mathrm{ml})$, NS4 (10.15 $\log$ CFU/ml), 015 (10.00 log CFU/ml), 298 (10.00 log $\mathrm{CFU} / \mathrm{ml}$ ) and $\mathrm{LBF}(9.40 \log \mathrm{CFU} / \mathrm{ml})$.

In another study, Hati et al. (2013) studied the growth and acidification of eight selected lactic acid bacteria in skim and soy milk. Among eight lactic cultures (S. thermophilus MD2, $L$. helveticus $\mathrm{V} 3$, L. rhamnosus NS6, L. rhamnosus NS4, L. bulgaricus NCDC 09, L. acidophilus NCDC 15, L. acidophilus NCDC 298 and L. helveticus NCDC 292) studied, L. bulgaricus NCDC 09 and $S$. thermophilus MD2 decreased the $\mathrm{pH}$ of skim and soy milk in greater extent. Acid production (i.e. titratable acidity) by $L$. bulgaricus NCDC 09 and L. helveticus $\mathrm{V} 3$ was higher than other strains. Higher viable counts were observed in S. thermophiles MD2 and L. helveticus V3. All the tested lactic acid bacteria performed better in skim milk as compared to soy milk. Hati et al. (2015) studied the growth performance of Lactobacillus 
Fig. 1 Changes in $\mathrm{pH}$ of goat milk by Lactobacillus cultures at different incubation hours

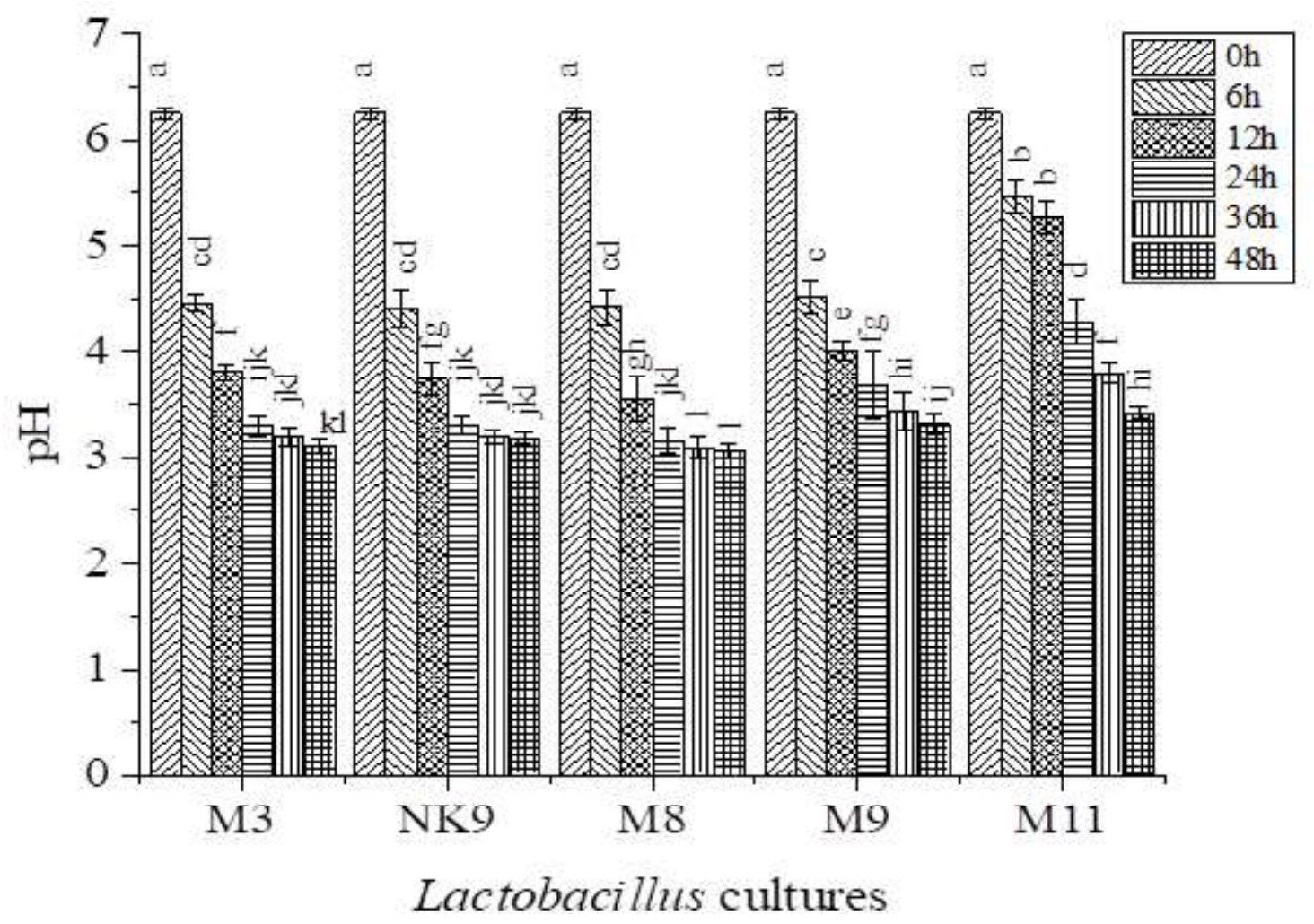

Fig. 2 Changes in lactic acid production (\%LA) by Lactobacillus cultures at different incubation hours in goat milk medium

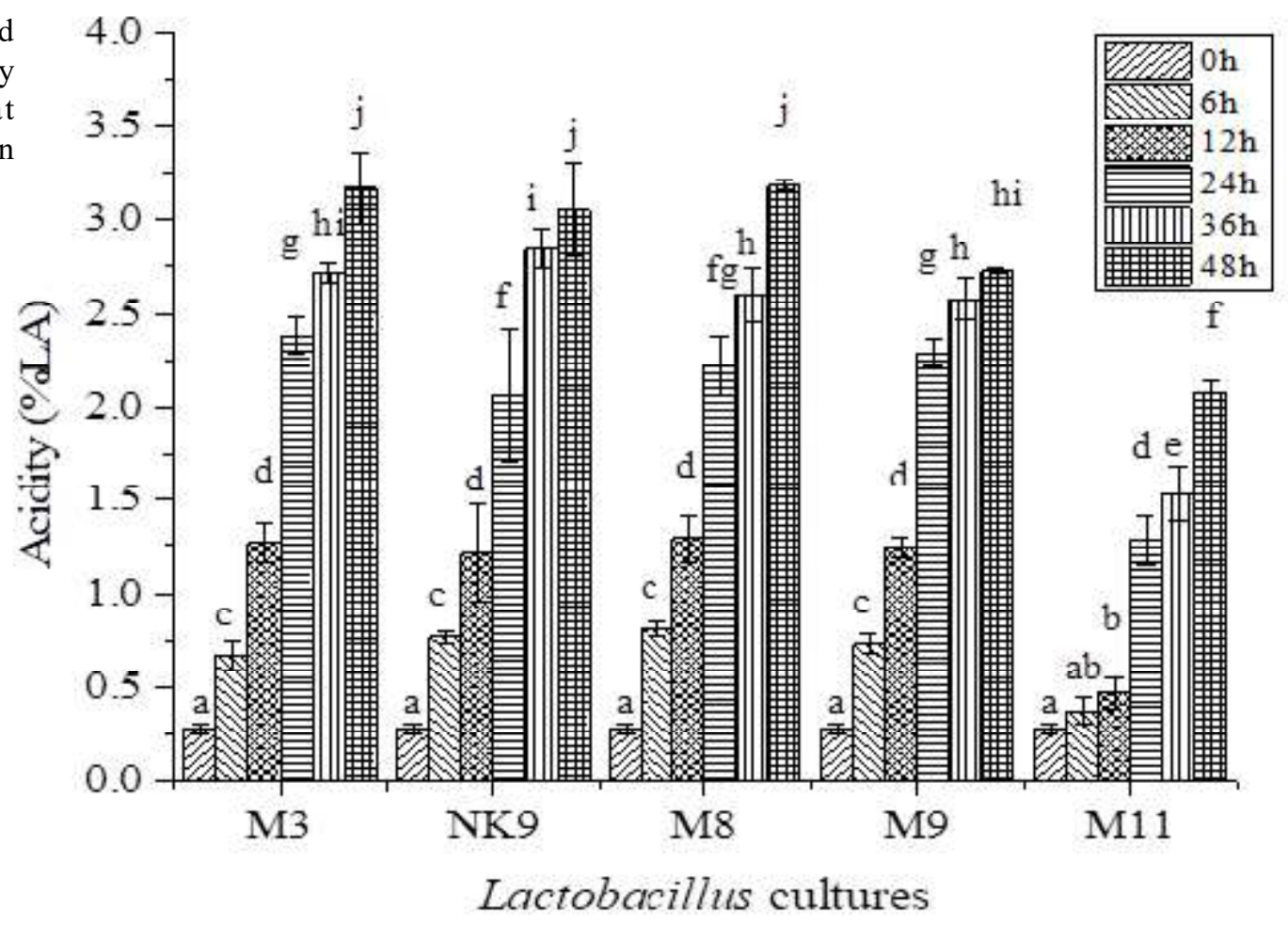

rhamnosus (NS4 and NS6), Lactobacillus helveticus MTCC 5463 (V3), Lactobacillus delbruckii (09), Enterococcus feacalis (ND3), Enterococcus feacalis (ND11) and Lactobacillus rhamnosus (SH8) by determining viable counts $(\log \mathrm{CFU} / \mathrm{ml})$ and production of Lactobacillus acid measured by decline in $\mathrm{pH}$ in skim milk inoculated at the rate of $1 \%$ and incubated at $37^{\circ} \mathrm{C}$ for $12 \mathrm{~h}$. It was observed that NS4 lowered down the $\mathrm{pH}$ at a maximum level compared to V3, ND3 and SH8. However, it was also observed 
Fig.3 Lactobacillus counts of different cultures at different incubation hours in goat milk medium

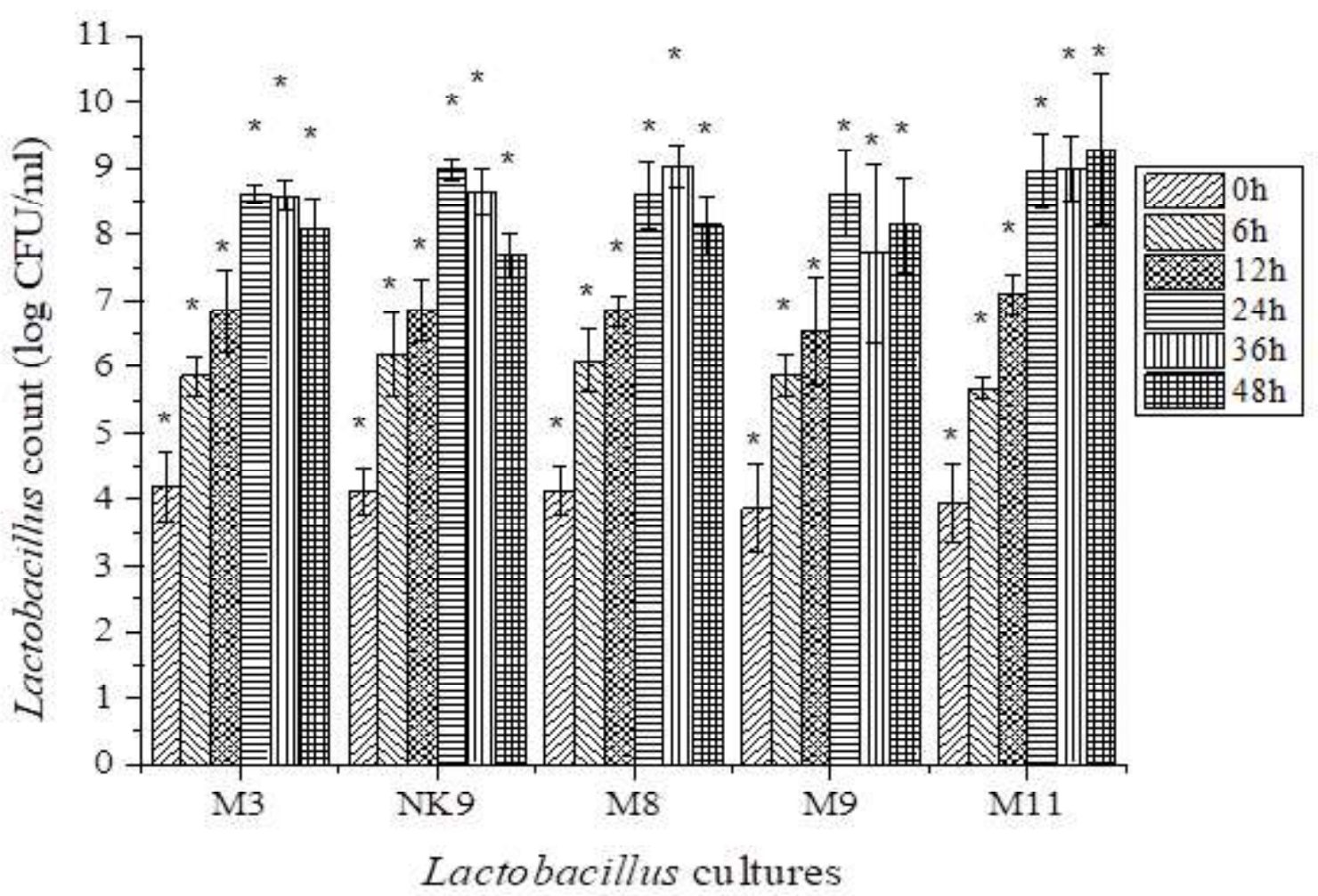

\#Values with different superscripts differ significantly $(p<0.05)$, Hydroxyl tree radical scavenging activity $(\%)$ Mean \pm SD.

that NS4 produced maximum acidity compared to V3, ND3, SH8 and I4. Viable counts of all the cultures were measured after $12 \mathrm{~h}$ of incubation at $37^{\circ} \mathrm{C}$. From the study, it was also found that NS4 gives the highest viable cell counts $10.68 \log \mathrm{CFU} / \mathrm{ml}$ than the other bacterial isolates at this specified growth conditions. V3 also showed higher viable cell counts and NS6 was relatively exhibited lesser bacterial counts compared to other isolates in MRS agar medium. It was concluded that viable cell counts, $\mathrm{pH}$ and acidity varies due to the use of different strains (Hati et al., 2015) as similar to our study.

\section{Antioxidant activity (ABTS assay) of fermented goat milk}

The antioxidant activity generally indicates the relative ability of antioxidants to scavenge the free radicals generated in the aqueous phase. The ABTS is generated by reacting a strong oxidizing agent (e.g., potassium permanganate or potassium persulfate) with the ABTS salt (Hati et al. 2013). From Table 1, it had been observed that antioxidant activity was differing significantly $(\mathrm{P}<0.05)$ with incubation periods. Also, there was a significant difference $(\mathrm{P}<0.05)$ observed within the cultures. Also, it was found that the antioxidant activity of all the five Lactobacillus cultures was increased significantly with the time of incubation.

The antioxidant activity (ABTS assay) of Lactobacillus cultures was found in the range of 42.14 to $53.27 \%$. NK9 had exhibited highest antioxidant activity (53.27\%), followed by M8 (51.99\%), M9 (50.55\%), M3 (45.85\%) and M11 (42.14\%) after $48 \mathrm{~h}$ at $37^{\circ} \mathrm{C}$.

Studies revealed the agreement with our work that Rahmawati and Suntornsuk (2016) found the antioxidant activity of goat milk yoghurt increase or constant during fermentation proceed or storage at 4R" $\mathrm{C}$ up to 21 days. The value of ABTS activity in per cent inhibition was almost $19 \%$ and then decrease after 21 days of storage. Similarly, Moreno-Montoro et al. (2017) evaluated the antioxidant activity of fermented goat milk. Different fractions of whey i.e. whey, cation exchange membrane retentate $\mathrm{R}$, permeate $\mathrm{P}$ of two fermented skimmed goat milk (ultra-filtered (UF) goat milk fermented with the classical starter bacteria or with the classical starter plus the Lactobacillus plantarum C4 probiotic strain) were assessed. The maximum value reaches was up to $0.4 \mu \mathrm{mol}$ Trolox equivalents per $\mathrm{mL}$ for ABTS radicals. In one study, Freire et al. (2017) evaluated ABTS activity of fermented goat milk beverage by Lactobacillus rhamnosus and Streptococcus thermophilus with or without addition of grape pomace on gut microbiota and showed that Antioxidant activity of formulation-1 (Goat milk, Sugar and Grape juice) was 418.02 \pm 16.14 mmol TE g" ${ }^{1}$ and formulation-2 (Goat milk, Sugar, Grape pomace extract and Grape juice) was $743.78 \pm 23.88 \mathrm{mmol} \mathrm{TE} \mathrm{g"1}$. Li et al. (2013) evaluated the antioxidant activities of goat milk casein and goat milk casein hydrolysates (hydrolysed by using a combination of neutral and alkaline proteases). They found that half-maximal inhibitory concentration $\left(\mathrm{IC}_{50}\right)$ value of ABTS 
activity of goat milk casein was $71.251 \pm 2.747 \mu \mathrm{g} / \mathrm{ml}$ and for goat milk casein hydrolysates was $0.449 \pm 0.027 \mu \mathrm{g} / \mathrm{ml}$. It indicating that goat milk casein hydrolysates is a good antioxidant compound with strong free radical scavenging activity compared with goat milk casein. One possible reason is that some peptides of goat milk casein hydrolysates are electron donors, which could react with free radicals, convert them to more stable products, and terminate the radical chain reaction.

\section{Hydroxyl free radical scavenging activity of fermented goat milk}

Hydroxyl radicals are reactive oxygen species that begin peroxidation of lipid membranes. Hydroxyl radicals are one of the most damaging free radicals in the body and can be an important mediator of damage to cell structures, nucleic acids, lipids and proteins. Hydroxyl free radical scavenging assay measures the relative ability of an antioxidant to scavenge the free radical generated in the aqueous phase (Li et al. 2008).

Hydroxyl free radical scavenging activity of all the five Lactobacillus cultures was presented in Table 2. From Table 2, it had been observed that hydroxyl free radical scavenging activity was differing significantly $(\mathrm{P}<0.05)$ with incubation periods. Also, there was a significant difference $(\mathrm{P}<0.05)$ observed within the cultures. Also, it was found that the hydroxyl free radical scavenging activity of all the five Lactobacillus cultures was increased significantly with the time of incubation. The hydroxyl free radical scavenging activity of Lactobacillus cultures was found in the range of 35.32 to $53.43 \%$. M8 had exhibited highest hydroxyl free radical scavenging activity (53.43\%), followed by M9 (50.98\%), NK9 (48.88\%), M3 (46.93\%) and M11 (35.32\%) after $48 \mathrm{~h}$ at $37^{\circ} \mathrm{C}$. It was observed that the percentage of hydroxyl free radical was increased with an increase in the incubation time from 0 to $48 \mathrm{~h}$.

Similar kind of observation was shown by Shu et al. (2018) reported hydroxyl free radical scavenging activity in goat milk fermented by Lactobacillus casei L61 and added the optimal additive amounts were $0.99 \%(\mathrm{w} / \mathrm{v})$ calcium lactate, $0.21 \%(\mathrm{w} / \mathrm{v})$ glucose, and $0.29 \%(\mathrm{w} / \mathrm{v})$ casein peptone. They found that the hydroxyl free radical scavenging rate increased significantly $(\mathrm{p}<0.001)$ from $56.50 \pm 0.57 \%$ to $88.01 \pm 0.69 \%$. In another study, Chen et al. (2019) investigated the hydroxyl free radicals scavenging activity of cheddar cheese during its ripening. They found that the activity of hydroxyl free radicals scavenging in cheese increased significantly in the first 4 weeks $(\mathrm{P}<0.05)$, and reached the maximum of $43.86 \%, 46.19 \%, 46.66 \%$ and $47.43 \%$. In the $20^{\text {th }}$ and $24^{\text {th }}$ weeks, all of them show the significant decrease $(\mathrm{P}<0.05)$. But in the last 3 weeks, no significant differences were observed $(\mathrm{P}>0.05)$. In the 16 th week, there were no significant differences $(\mathrm{P}>0.05)$ between mixed and individual probiotic cheese, however, the value of mixed one was significantly higher than that of control cheese $(\mathrm{P}<0.05)$. In our study, we also found the same observation with the significant increase of hydroxyl free radicals-scavenging activity than the control $(0 \mathrm{~h})$.

\section{Superoxide free radical scavenging activity of fermented goat milk}

Superoxide free radical scavenging assay measures the relative ability of an antioxidant to scavenge the free radical generated in the aqueous phase. The original pyrogallol (1,2,3-trihydroxy benzene) method, which was developed specifically for superoxide dismutase, is widely used for measuring superoxidescavenging of other antioxidants spectrophotometrically at 320 nm (Liu et al. 2010).

Superoxide free radical scavenging activity of all the five Lactobacillus cultures was depicted in Table 3. From Table 3, it had been observed that superoxide free radical scavenging activity was differing significantly $(\mathrm{P}<0.05)$ with incubation periods. Also, there was a significant difference $(\mathrm{P}<0.05)$ observed within the cultures. Also, it was found that the superoxide free

Table 1 Antioxidant activity (\%) of Lactobacillus cultures (ABTS assay)

\begin{tabular}{llllll}
\hline Lactobacillus Cultures & Oh & $12 \mathrm{~h}$ & $24 \mathrm{~h}$ & $36 \mathrm{~h}$ & $48 \mathrm{~h}$ \\
\hline M3 & $2.51 \pm 0.76^{\mathrm{a}}$ & $10.19 \pm 1.34^{\mathrm{b}}$ & $20.87 \pm 2.00^{\mathrm{d}}$ & $31.62 \pm 1.76^{\mathrm{f}}$ & $45.85 \pm 4.07^{\mathrm{i}}$ \\
NK9 & $2.49 \pm 0.77^{\mathrm{a}}$ & $15.45 \pm 0.50^{\mathrm{c}}$ & $29.79 \pm 1.77^{\mathrm{ef}}$ & $44.41 \pm 1.70^{\mathrm{hi}}$ & $53.27 \pm 1.54^{\mathrm{i}}$ \\
M8 & $2.48 \pm 0.76^{\mathrm{a}}$ & $15.06 \pm 1.91^{\mathrm{c}}$ & $20.87 \pm 2.00^{\mathrm{d}}$ & $40.48 \pm 1.58^{\mathrm{g}}$ & $51.99 \pm 1.01^{\mathrm{j}}$ \\
M9 & $2.49 \pm 0.76^{\mathrm{a}}$ & $14.67 \pm 1.84^{\mathrm{c}}$ & $26.74 \pm 2.77^{\mathrm{e}}$ & $33.33 \pm 1.93^{\mathrm{f}}$ & $50.55 \pm 1.34^{\mathrm{i}}$ \\
M11 & $2.49 \pm 0.77^{\mathrm{a}}$ & $04.98 \pm 1.04^{\mathrm{a}}$ & $15.06 \pm 2.00^{\mathrm{c}}$ & $23.03 \pm 1.02^{\mathrm{d}}$ & $42.14 \pm 7.16^{\text {gh }}$ \\
\hline
\end{tabular}

Table 2 Hydroxyl free radical scavenging activity (\%) of Lactobacillus cultures

\begin{tabular}{llllll}
\hline Lactobacillus Cultures & Oh & $12 \mathrm{~h}$ & $24 \mathrm{~h}$ & $36 \mathrm{~h}$ & $48 \mathrm{~h}$ \\
\hline M3 & $0.31 \pm 0.22^{\mathrm{a}}$ & $07.70 \pm 2.50^{\mathrm{b}}$ & $32.91 \pm 0.85^{\mathrm{e}}$ & $40.15 \pm 1.50^{\mathrm{hi}}$ & $46.93 \pm 0.81^{\mathrm{lm}}$ \\
NK9 & $0.31 \pm 0.21^{\mathrm{a}}$ & $11.32 \pm 1.07^{\mathrm{c}}$ & $33.08 \pm 0.85^{\mathrm{ef}}$ & $43.20 \pm 1.45^{\mathrm{jk}}$ & $48.88 \pm 4.72^{\mathrm{mn}}$ \\
M8 & $0.33 \pm 0.22^{\mathrm{a}}$ & $05.96 \pm 1.61^{\mathrm{b}}$ & $37.88 \pm 2.00^{\mathrm{gh}}$ & $40.82 \pm 0.71^{\mathrm{ij}}$ & $53.43 \pm 0.86^{\mathrm{j}}$ \\
M9 & $0.31 \pm 0.21^{\mathrm{a}}$ & $11.04 \pm 1.12^{\mathrm{c}}$ & $38.80 \pm 1.77^{\mathrm{hi}}$ & $44.83 \pm 0.70^{\mathrm{kl}}$ & $50.98 \pm 1.54^{\mathrm{n}}$ \\
M11 & $0.32 \pm 0.21^{\mathrm{a}}$ & $01.77 \pm 1.05^{\mathrm{a}}$ & $19.95 \pm 0.71^{\mathrm{d}}$ & $35.57 \pm 2.80^{\mathrm{fg}}$ & $35.82 \pm 1.96^{\mathrm{g}}$ \\
\hline
\end{tabular}


radical scavenging activity of all the five Lactobacillus cultures was increased significantly with the time of incubation.

The superoxide free radical scavenging activity of Lactobacillus cultures was found in the range of $24.34 \%$ to $50.99 \%$. NK9 had exhibited highest superoxide free radical scavenging activity (50.99\%), followed by M3 (48.68\%), M8 (41.14\%), M9 (36.13\%) and M11 (24.34\%) after $48 \mathrm{~h}$ at $37^{\circ} \mathrm{C}$. It was observed that the percentage of superoxide free radical was increased with an increase in the incubation time from 0 to $48 \mathrm{~h}$. At $0 \mathrm{~h}$, there was no superoxide free radical scavenging activity found in fermented goat milk produced by Lactobacillus cultures.

Similarly kind of observation reported by Shu et al. (2017). They optimized rate of addition of prebiotic was inulin $(0.6 \%)$, xylooligosaccharide $(0.6 \%)$, galacto-oligosaccharide $(0.6 \%)$ and fructo-oligosaccharide $(0.4 \%)$ and value of superoxide free radical were $21.09 \%, 18.20 \%, 27.61 \%$ and $29.92 \%$, respectively. In another study, superoxide radical scavenging activity of fermented goat milk product was evaluated by Liu et al. (2016). They compared the antioxidant properties of cow milk, goat milk, cow milk kefir and goat milk kefir and showed that maximum $(4.0 \mathrm{mg} / \mathrm{ml})$ dose level of kefir gives better superoxide radical scavenging activity i.e. almost $70 \%$ for both kefir compare to milk. This same kind of observation found in our case because fermentation was increase superoxide radical scavenging activity compares to control. In one study, Shu et al. (2016) optimized the different condition for best superoxide free radical scavenging activity for goat milk casein hydrolysates by alcalase. The value of superoxide free radical scavenging activity at different condition was like, at temperature $50^{\circ} \mathrm{C}(36.08 \%)$, at $\mathrm{pH} 8(85.36 \%)$, at enzyme to substrate ratio $1.5 \%(43.01 \%)$, at $150 \mathrm{~min}$ hydrolysis time $(46.13 \%)$ and also found increase in superoxide free radical scavenging activity with time of hydrolysis as we seen in our study.

\section{Proteolytic (OPA) activity of fermented goat milk}

The proteolytic (OPA) activity of all the five Lactobacillus cultures was presented in Table 4. From Table 4, it had been observed that proteolytic (OPA) activity was differing significantly $(\mathrm{P}<0.05)$ with incubation periods. Also, there was a significant difference $(\mathrm{P}<0.05)$ observed within the cultures. It was found that the proteolytic (OPA) activity of all the five Lactobacillus cultures was increased non-significantly with the time of incubation.

The proteolytic (OPA) activity of Lactobacillus cultures was found in the range of 7.30 to $9.96 \mathrm{mg} / \mathrm{ml}$. M9 had exhibited highest proteolytic (OPA) activity $(9.96 \mathrm{mg} / \mathrm{ml})$, followed by M3 $(9.08$ $\mathrm{mg} / \mathrm{ml}), \mathrm{NK} 9(8.62 \mathrm{mg} / \mathrm{ml}), \mathrm{M} 8(8.37 \mathrm{mg} / \mathrm{ml})$ and M1 $1(7.30 \mathrm{mg} / \mathrm{ml})$ after $48 \mathrm{~h}$ at $37^{\circ} \mathrm{C}$. It was also observed that the proteolysis was increased with an increase in the incubation time from 0 to $48 \mathrm{~h}$.

Basically, Increase in proteolytic activity with the different incubation periods was directly proportional to the number of amino acids required by the Lactobacillus cultures during their growth phases based upon which the release of free $\mathrm{NH}_{3}$ groups. It was also reported that the extent of proteolysis showed to be the time and strain-dependent (Donkar et al. 2007). In agreement of our work, Parmar et al. (2018) evaluated the proteolytic activity of goat milk fermented by NK9 (Lb. casei) and LF (Lb. fermentum TDS030603 (MTCC25067)). They optimized the rate of inoculation $(1.0,1.5$ and $2.0 \%)$ and incubation period $(0,6,12,24$ and $48 \mathrm{~h})$ by OPA method. They found that $2 \%$ inoculation rate and $48 \mathrm{~h}$ of incubation gives the best proteolytic activity for both cultures i.e. for NK9 $(7.598 \mathrm{mg} / \mathrm{ml})$ and LF $(9.709 \mathrm{mg} / \mathrm{ml})$. Karthikeyan et al. (2018) isolated eight LAB from goat milk. They screened that isolates on the basis of proteolytic activity on skim milk agar. After its genotypic and phenotypic evaluation, found that $L b$.

Table 3 Superoxide free radical scavenging activity (\%) of Lactobacillus cultures

\begin{tabular}{llllll}
\hline Lactobacillus Cultures & Oh & $12 \mathrm{~h}$ & $24 \mathrm{~h}$ & $36 \mathrm{~h}$ & $48 \mathrm{~h}$ \\
\hline M3 & $0.00 \pm 0.00^{\mathrm{a}}$ & $0.00 \pm 0.00^{\mathrm{a}}$ & $16.43 \pm 2.84^{\mathrm{c}}$ & $32.07 \pm 1.84^{\mathrm{f}}$ & $48.68 \pm 1.05^{\mathrm{i}}$ \\
NK9 & $0.00 \pm 0.00^{\mathrm{a}}$ & $0.43 \pm 0.75^{\mathrm{a}}$ & $21.29 \pm 2.67^{\mathrm{d}}$ & $29.73 \pm 0.69^{\mathrm{f}}$ & $50.99 \pm 2.30^{\mathrm{i}}$ \\
M8 & $0.00 \pm 0.00^{\mathrm{a}}$ & $0.88 \pm 0.88^{\mathrm{a}}$ & $10.80 \pm 2.62^{\mathrm{b}}$ & $25.82 \pm 1.86^{\mathrm{e}}$ & $41.14 \pm 2.64^{\mathrm{h}}$ \\
M9 & $0.00 \pm 0.00^{\mathrm{a}}$ & $0.17 \pm 0.29^{\mathrm{a}}$ & $08.74 \pm 2.93^{\mathrm{b}}$ & $17.55 \pm 1.10^{\mathrm{c}}$ & $36.13 \pm 2.81^{\mathrm{g}}$ \\
M11 & $0.00 \pm 0.00^{\mathrm{a}}$ & $0.00 \pm 0.00^{\mathrm{a}}$ & $02.73 \pm 2.38^{\mathrm{a}}$ & $15.84 \pm 2.22^{\mathrm{c}}$ & $24.34 \pm 1.83^{\mathrm{e}}$ \\
\hline
\end{tabular}

\#Values with different superscripts differ significantly $(p<0.05)$, Superoxide free radical scavenging activity $(\%)$ Mean \pm SD.

Table 4 Proteolytic activity (mg/ml) of Lactobacillus cultures (OPA activity)

\begin{tabular}{llllll}
\hline Lactobacillus Cultures & Oh & $12 \mathrm{~h}$ & $24 \mathrm{~h}$ & $36 \mathrm{~h}$ & $48 \mathrm{~h}$ \\
\hline M3 & $2.49 \pm 0.03^{*}$ & $4.69 \pm 0.37^{*}$ & $6.40 \pm 0.55^{*}$ & $7.05 \pm 0.37^{*}$ & $9.08 \pm 0.93^{*}$ \\
NK9 & $2.30 \pm 0.15^{*}$ & $5.49 \pm 0.82^{*}$ & $6.76 \pm 0.43^{*}$ & $7.81 \pm 0.78^{*}$ & $8.62 \pm 0.93^{*}$ \\
M8 & $2.40 \pm 0.11^{*}$ & $5.06 \pm 0.72^{*}$ & $6.11 \pm 0.54^{*}$ & $6.93 \pm 0.52^{*}$ & $8.37 \pm 1.04^{*}$ \\
M9 & $2.33 \pm 0.11^{*}$ & $5.72 \pm 1.12^{*}$ & $7.35 \pm 0.33^{*}$ & $9.11 \pm 1.28^{*}$ & $9.96 \pm 0.67^{*}$ \\
M11 & $2.37 \pm 0.02^{*}$ & $4.01 \pm 0.27^{*}$ & $5.03 \pm 0.85^{*}$ & $6.34 \pm 0.48^{*}$ & $7.30 \pm 0.69^{*}$ \\
\hline
\end{tabular}

*Values with different superscripts differ non-significantly $(p<0.05)$, Proteolytic activity $(\mathrm{mg} / \mathrm{ml}) \mathrm{Mean} \pm \mathrm{SD}$. 
delbrueckii had the best proteolytic activity (maximum $3 \mathrm{~mm}$ zone was hydrolysed). In order to isolate LAB from spontaneous fermented local goat milk, which had proteolytic activity and used for further fermentation of goat milk. Based on proteolytic activity, the isolates composed of two bacteria species namely Lactobacillus plantarum (YN 1.1, YN 1.3, YN 1.8 and isolates YN 2.25) and another bacteria was Lactobacillus pentosus (YN 1.6). Five isolates had proteolytic activity, where three of them had the best proteolytic activity namely Lactobacillus plantarum YN 1.1, Lactobacillus plantarum YN 1.3 and Lactobacillus pentosus YN 1.6 (Yelnetty et al., 2014). In a study, nineteen Lactobacillus isolated from Algerian goat's milk, 13 belonging to $L b$. plantarum, three to $L b$. pentosus, two to Lb. rhamnosus and one to $L b$. fermentum, were examined in vitro used as adjunct culture in dairy products. The strains were tested for their proteolytic activity, sensory and safety properties. Strains LbMS16 and LbMS21 Lb. plantarum and LbMF25 Lb. rhamnosus presented the highest proteolytic activity (Ahmed and Bousmaha-Marroki, 2014).

\section{Conclusions}

Lb. rhamnosus (M8) showed highest $\mathrm{pH}$ reduction, maximum acidity and Lactobacillus counts i.e. 3.06, 3.18\%LA and $9.03 \mathrm{log}$ $\mathrm{CFU} / \mathrm{ml}$, respectively during the fermentation of goat milk after $48 \mathrm{~h}$ at $37^{\circ} \mathrm{C}$ than other cultures. Antioxidant activity (ABTS assay) of Lactobacillus cultures were found in the range of 42.14 to $53.27 \%$ and maximum antioxidant activity was shown by $L b$. casei (NK9) culture. The hydroxyl free radical scavenging activity of Lactobacillus cultures was found in the range of 35.32 to $53.43 \%$ and highest was observed in Lb. rhamnosus (M8) culture. The superoxide free radical scavenging activity of Lactobacillus cultures was found in the range of $24.34 \%$ to $50.99 \%$ and the maximum was presented by Lb. casei (NK9) culture. The proteolytic (OPA) activity of Lactobacillus cultures was found in the range of 7.30 to $9.96 \mathrm{mg} / \mathrm{ml}$ and the maximum was exhibited by Lb. rhamnosus (M9). However, M8, NK9 and M9 could be used for the development of functional fermented goat milk.

\section{Acknowledgments}

We are thankful to Instructional Livestock Farm Complex (ILFC), Veterinary College, AAU, Anand for providing goat milk during the study.

\section{References}

Ahmed M, Bousmaha-Marroki L (2014) Lactobacilli isolated from Algerian goat's milk as adjunct culture in dairy products. Brazilian Arch Biol Technol 57: 1678-4324

Badis A, Guetarni D, Moussa Boudjema B, Henni DE, Kihal M (2004) Identification and technological properties of lactic acid bacteria isolated from raw goat milk of four Algerian races. Food Microbiol 21: $579-588$
Ceballos LS, Morales ER, Adarve GDT, Castro JD, Martinez LP, Sanz MR (2009) Composition of goat and cow milk produced under similar conditions and analyzed by identical methodology. J Food Compos Anal 22: 322-329

Chen L, Deng H, Cui H, Fang J, Zuo Z, Deng J, Zhao L (2018) Inflammatory responses and inflammation-associated diseases in organs. Oncotarget 9: 7204-7209

Chen P, Liu L, Zhang X, Massounga Bora AF, Li X, Zhao M, Wang Y (2019) Antioxidant activity of Cheddar cheese during its ripening time and after simulated gastrointestinal digestion as affected by probiotic bacteria. Int J Food Prop 22: 217-228

CIRG (2015-2016) Annual Report. Executive Summary. Published by Director, ICAR-CIRG, Makhdoom, Farah, Mathura, 281122, UP, $1-175$.

da Costa WKA, de Souza EL, Beltrao-Filho EM, Vasconcelos GKV, SantiGadelha T, de Almeida Gadelha CA, Magnani M(2014) Comparative protein composition analysis of goat milk produced by the Alpine and Saanen breeds in northeastern Brazil and related antibacterial activities. PLoS One 9: e93361

Da Silva FFP, Biscola V, Jean Guy LeBlanc JG, Melo Franco BDG (2016) Effect of indigenous lactic acid bacteria isolated from goat milk and cheeses on folate and riboflavin content of fermented goat milk. Food Sci Technol 71: 155-161

Donkar ON, Henriksson A, Vasiljevic T, Shah NP (2007) Proteolytic activity of dairy lactic acid bacteria and probiotics as determinant of growth and in vitro angiotensin converting enzyme inhibitory activity in fermented milk. Le Lait 86: 21-38

Freire FC, Adorno MAT, Sakamoto IK, Antoniassi R, Chaves ACSD, dos Santos KMO, Sivieri K (2017) Impact of multi-functional fermented goat milk beverage on gut microbiota in a dynamic colon model. Food Res Int 99: 315-327

Hati S, Patel N, Mandal S (2013) Comparative growth behaviour and bio functionality of lactic acid bacteria during fermentation of soy milk and bovine milk. Probiotics Antimicrob Proteins 5: 233-286

Hati S, Sreeja V, Solanki J, Prajapati JB (2015) Influence of proteolytic lactobacilli on ACE inhibitory activity and release of bioactive peptides. Indian J Dairy Sci 68: 1-8

IDF International Dairy Federation (146:2003) Yogurt-Identification of characteristic microorganisms (Lactobacillus delbrueckii supsp. bulgarius and Streptococcus thermophilus). http:// www.dairyinfo.gc.ca/index_e.php?s1=fil-idf\&s2=pub\&s3=iso. Accessed 23 May 2019

Indian Standards (1960) Methods of test for dairy industry part-I rapid examination of milk. Indian Standards Institution, New Delhi (1479).

Indian Standards (1961) Methods of test for dairy industry part-II chemical analysis of milk. Indian Standards Institution, New Delhi (1479).

Karthikeyan G, Palanisamy A, Madheshwar RV, Sudhakar N (2018) Milk clotting and proteolytic activity of protease enzyme from Lactobacillus delbrueckii isolated from raw goat milk. Aust J Pharm Biol 1: 15-26

Kondyli E, Katsiari MC, Voutsinas LP (2007) Amino acid composition and nutritional value of goat milk from the indigenous Greek breed. Milchwissenschaft 62: 164-166

Li Y. Jiang B, Zhang T, Mu W, Liu J (2008) Antioxidant and free radicalscavenging activities of chickpea protein hydrolysate (CPH). Food Chem 106: 444-450

Li Z, Jiang A, Yue T, Wang J, Wang Y, Su J (2013) Purification and identification of five novel antioxidant peptides from goat milk casein hydrolysates. J Dairy Sci 96: 4242-4251 
Liu M, Bayjanov JR, Renckens B, Nauta A, Siezen RJ (2010) The proteolytic system of lactic acid bacteria revisited: a genomic comparison. BMC Genomics 11: 36-43

Liu R, Xing L, Fu Q, Zhou GH, Zhang WG (2016) A review of antioxidant peptides derived from meat muscle and by-products. Antioxidants 5 : $32-45$

Mahdi C, Untari H, Padaga MC (2018) Identification and Characterization of Bioactive Peptides of Fermented Goat Milk as a Sources of Antioxidant as a Therapeutic Natural Product. International Conference on Chemistry and Material Science. doi:10.1088/1757899X/299/1/012 014/pdf

Moreno-Montoro M, Olalla-Herrera M, Rufián-Henares JA, Martínez RG, Miralles B, Bergillos T, Jauregi P (2017) Antioxidant, ACE-inhibitory and antimicrobial activity of fermented goat milk: activity and physicochemical property relationship of the peptide components. Food Funct 8: 2783-2791

Park YW (2009) Bioactive components in goat milk. In: Park YW (ed) Bioactive components in milk and dairy products, $1^{\text {st }}$ edn. WileyBlackwell, Hoboken, NJ, USA, pp. 43-81)

Parmar H, Hati S, Sakure A (2018) In vitro and in silico analysis of novel ACE-inhibitory bioactive peptides derived from fermented goat milk. Int J Pept Res Ther 24: 441-453

Rahal A, Kumar A, Singh V, Yadav B, Tiwari R, Chakraborty S, Dhama K (2014) Oxidative stress, prooxidants, and antioxidants: the interplay. Biomed Res Int 2014: 1-19

Rahmawati IS, Suntornsuk W (2016) Effects of fermentation and storage on bioactive activities in milks and yoghurts. Procedia Chem 18: $53-62$

Samaranayaka AGP, Li-Chan ECY (2011) Food-derived peptidic antioxidants: A review of their production, assessment and potential applications. J Funct Foods 3: 229-254

Sharma G, Rout PK, Kaushik R, Sing G (2017) Identification of bioactive peptides in goat milk and their health application. Adv Dairy Res 5: 191-196

Shu G, Shi X, Chen L, Kou J, Meng J, Chen H (2018) Antioxidant peptides from goat milk fermented by Lactobacillus casei L61: preparation, optimization, and stability evaluation in simulated gastrointestinal fluid. Nutrients 10: 797-810

Shu G, Wang Z, Chen L, Zhang Q, Xin N (2017) Enzymolysis technology optimization for production of antioxidant peptides from goat milk casein. J Lucian Blaga 21: 51-60

Shu G, Zhang B, Zhang Q, Wan H, Li H (2016) Effect of temperature, pH, enzyme to substrate ratio, substrate concentration and time on the antioxidative activity of hydrolysates from goat milk casein by alcalase. Food Technol 20: 29-38

Solanki D, Hati S, Sakure A (2017) In Silico and in vitro analysis of novel angiotensin i-converting enzyme (ace) inhibitory bioactive peptides derived from fermented camel milk (Camelus dromedarius). Int $\mathbf{J}$ Pept Res Ther 19: 275-380

Steel RGD, Torrie JH (1980) Principles and procedure of statistics- a biometrical approach. Mcgraw Hill Kogakusha Ltd., Japan

Urso ML, Clarkson PM (2003) Oxidative stress, exercise, and antioxidant supplementation. Toxicology 189: 41-54

Yelnetty A, Purnomo H, Mirah A (2014) Biochemical characteristics of lactic acid bacteria with proteolytic activity and capability as starter culture isolated from spontaneous fermented local goat milk. J Nat Sci Res 4: 2224-3186

Zenebe T, Ahmed N, Kabeta T, Kebede G (2014) Review on medicinal and nutritional values of goat milk. Acad J Nutr 3: 30-39

Zervas G, Tsiplakou E (2011) The effect of feeding systems on the characteristics of products from small ruminants. J Small Ruminant Res 101: 140-149 